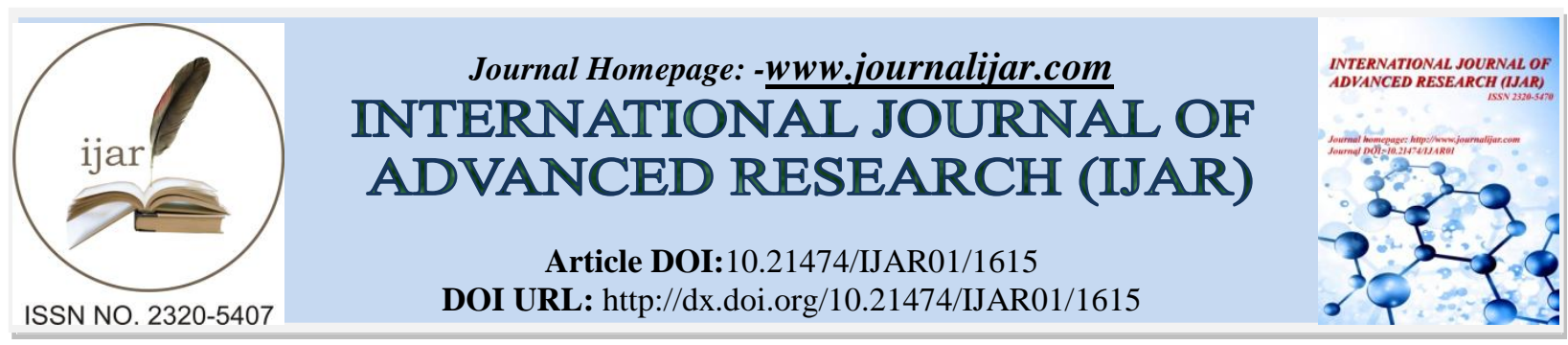

RESEARCH ARTICLE

\title{
A.P.J ABDUL KALAM: A VISIONARY FOR THE YOUTH, WITH SPECIAL REFERENCE TO THE IGNITED MINDS.
}

1. Research Scholar.

"Ayuta Mohanty ${ }^{1}$ and Puspita Das ${ }^{2}$.

2. Associate Professor.

\section{Manuscript Info}

Manuscript History

Received: 15 July 2016

Final Accepted: 22 August 2016

Published: September 2016

Key words:-

Ignited minds, youth, Kalam,

vision, developed country, india.

\begin{abstract}
In the words of the famous Scottish novelist and playwright J.M. Barrie, "I'm youth, I'm joy, I'm a little bird that has broken out of the egg". When a little bird comes out of the egg, there stands a whole new and beautiful world in front of that tiny creature and this new world fills the heart of the bird with new aspirations and hopes to soar high in the sky. Similar is the case of the young people as during this period they have before them new vistas of knowledge and their hearts are filled with new aspirations to achieve big. Youth is often termed as the 'spring of life' as this is the time of freshness and flowering in life of a person. It is the time of fearless experimentation and dreaming of making impossibilities possible. The youth have the strength to work towards bigger cause. They are the future of a country and can play a great role in moulding the destiny of a nation. Late former President Dr. A.P.J. Abdul Kalam had tremendous faith in the power of youth in constructing the future of a country. He believed that young minds have superfluous possibilities and potentials that if equipped with knowledge and creativity can work wonders for a country. This paper throws light on Dr. Kalam's views on the role of the youth in making India a developed country as stated in his book Ignited Minds.
\end{abstract}

Copy Right, IJAR, 2016,. All rights reserved.

Dr. A. P. J. Abdul Kalam was one of India's most distinguished scientist, $11^{\text {th }}$ President of India and the recipient of the most prestigious Bharat Ratna, Padma Bhushan and Padma Vibhushan-the country's three highest civilian honours. Due to his great contribution in the field of space research and missile development, he came to be known as the 'Missile Man of India'. In spite of being such an eminent personality, he remained humane and humble throughout his life. Though he came from a poor family, he was a hardworking and dedicated person, with an unquenchable thirst for knowledge and learning. He believed that every single person he met can help him in learning something new. He narrates in his books, all his stimulating experiences with students, young people, teachers, scientists, politicians, saints and seers. According to an editorial of the prestigious e-newspaper The Hindu, "More than as a scientist and a technocrat, Kalam will be remembered for his tenure as India's $11^{\text {th }}$ President, when he moved the institution away from being merely formal and ceremonial in nature. He used the presidency as a platform to inspire youth, who were readily impressed by his earthy demeanour and discursive approach to public speaking." He was the only President of India who broke the tradition of his position, reached ordinary people, 
listened to their grievances and won their love and affection. That is why he is generally known as the 'People's President.'

Dr. Abdul Kalam remained accessible to the youth. He tried to reach the youth of our country and inspired them to become responsible citizens of our country and to contribute something to its development. He always dreamt of making India a developed country. Dr. Kalam used to say that if people will remember him as a good teacher that would be the utmost privilege for him. He had a firm belief in the tremendous potential of the youth of our country. He aimed at motivating India's people, especially its youth for the development of our country. According to Dr. Kalam, throughout his career in Science and Technology, he had always counted upon the power and prospects of the youth. In his book Ignited Minds, he wrote, "My strength has been my young teams who never let me down. And what satisfaction there was in working with them on some of the most complex projects in some of the most challenging situations! Given the freedom to achieve and guided properly, I am convinced the young of India can accomplish far more.” (Ignited Minds, Preface ix-x)

In his book Ignited Minds, Dr. A.P.J. Abdul Kalam has discussed how the "untapped" potentials of the young people of India can be utilized properly to achieve the goal of making India a fully developed country. According to him, the young people have developed a subjugated and docile attitude. They very often settle for less than what they deserve. That is why in spite of having skills, resources and talents India is not that much prosperous and developed as it should have been. Through Ignited Minds, Dr. Kalam aimed to motivate the youth to "get back on the winning track and unleash the energy within a nation that hasn't allowed itself full rein." In this book he has analyzed various issues that can accelerate the winning streak of today's youth.

Kalam has stressed the importance of a role model in the life of children and youth. He points out that a person needs different role models in different stages of his life and how role models can help him to achieve success in personal front, professional life as well as in contributing something for our nation. He also adds how great teachers and scientists can ignite the young minds through their vision for the benefit of our country. Dr. Abdul Kalam always insisted the youth to dream, not only to dream but to dream big. He used to say, "Dream, dream, dream. Dreams transform into thoughts and thoughts result in action" (Ignited Minds, 1). But he also advised them to strengthen their spiritual wisdom. He believed that upholding the value system is as important as prosperity through wealth generation.

India takes its pride in the slogan 'Unity in Diversity'. India has diverse geographical locations, regional diversity, cultural diversity, linguistic variations, ethnic diversity and diversity in religion. Religious diversity is one of the most conspicuous spirits of Indian society. All types of religions of the world are found here like Hinduism, Buddhism, Jainism, Christianity, Zoroastrianism, Islam and Sikhism. But now-a-days, politics is overshadowing religious sentiments. Politicians are using religion as a weapon to create a rift between people to secure their seats. But according to Dr. Abdul Kalam, diverse religions add new dimensions to the 'Indianness' (Ignited Minds, 115) of the people. He wrote, "The greatest danger to our sense of unity and our sense of purpose comes from those ideologists who seek to divide the people. The Indian Constitution bestows on all the citizens total equality under its protective umbrella. What is now cause for concern is the trend toward putting religious form over religious sentiments." (Ignited Minds, 115) He believed that for India to prosper what we need is just pure patriotism, beyond politics and religion. If all the people of India come together, leaving behind all forms of diversities, to create a harmonious India, that will be our greatest strength. To make this vision turn into reality, the youth can play a major role.

Dr. Kalam had identified five areas where Indian youth can cater essential aptitude and these areas if tackled together can create great opportunities for the development of India. These five areas are agriculture, power, education and health care, information technology and the strategic sector. Since times immemorial India has always been considered as an agricultural country. Improvements in agricultural sector will ensure higher economic growth. Developments in education and health care will create scope for more and efficient manpower. Information technology sector is growing with passing of time and its further growth will accelerate the development process. Electric power yields energy security essential for the growth of all other sectors. Development in strategic sector, like nuclear, space and defence technology, are quite crucial for strengthening the power of our country. All these five areas, if developed in integration, will strengthen the backbone of our country and India would march ahead in the path of becoming a developed country. 
According to Dr. Kalam's opinion, if something is at risk, then "human mind gets ignited" (Ignited Minds, 177) and the quality of the work gets amplified. He used to advise the youth to remember that challenges guide us to opportunities. When one picks up a work, he should perform it with complete dedication and diligence, without thinking of what the result would be. If he succeeds in the work, the success should act as an inspiration for future goals and if it fails, then the experience should be taken as a lesson for the next time. Failures should not restrict them from trying; rather they should use them as stepping stones for their success in futureendeavors. Hopes and aspirations must remain alive till the last breath as they motivate us to be successful in every sphere. He wrote in Ignited Minds, "The young especially has to be guided properly, so that their lives find a proper direction and their creativity is allowed to flower." (Ignited Minds, 178)

Kalam concluded the book with an excellent piece of poetry that brilliantly conveys to the young minds the message he wished to impart. It is not only a poem but looks more like a pledge. It seems as if Kalam, through this poem, wanted the youth of India to take this pledge and work according to it. This poem intends to ignite the young souls of India and motivate them to work towards a greater vision- the vision of making India a developed country. The poem is titled 'Song of Youth' (Ignited Minds, 196):

"As a young citizen of India, armed with technology, knowledge and love for my nation, I realize, small aim is a crime.

I will work and sweat for a great vision, the vision of transforming India into a developed nation powered by economic strength with value system.

I am one of the citizens of a billion, only the vision will ignite the billion souls.

It has entered into me,

the ignited soul compared to any resource,

is the most powerful resource

on the earth, above the earth and under the earth.

I will keep the lamp of knowledge burning

to achieve the vision-Developed India."

This 'Song of Youth' shows how strong faith Kalam had on the youth of his country. He believed that it is the youth who has the power to change the future of our country and fulfil his dream of making India a developed country. He visited schools and colleges in different parts of the country to spread the message that the youth should prepare themselves to make India a developed nation. "Ignite your mind and think big" (Ignited Minds, 187) was the message he imparted to the students. Kalam always considered the interests and needs of the nation greater than that of an individual. He wanted to embed this thought in the minds of the youth of our country. He wrote "when thousands recite this, I see the developed India" (Ignited Minds, 195). Dr. A.P.J. Abdul Kalam's book Ignited Minds shows what a true patriot he was and inspires the youth of the country to explore the unexplored paths to convert India into a developed and prosperous nation. This book shows the reason why A.P.J Abdul Kalam was and will always be the Youth Icon and a role model for large number of young people of our country.

\section{References:-}

1. Kalam, A.P.J. Abdul. Ignited Minds. New Delhi: Penguin India Pvt, 2003. Print.

2. "Igniting Minds." The Hindu. N.p., 29 July 2015. Web. 1 Sept. 2016.

3. "Books: Dr. A.P.J. Abdul Kalam: Former President of India: Speeches." Books: Dr. A.P.J. Abdul Kalam: Former President of India: Speeches. N.p., n.d. Web. 10 Sept. 2016. 